\title{
Integrating youth into the full life and work of the church - in worship
}

Prof Malan Nel

\section{INTRODUCTION}

I would like to thank you for the privilege of partaking in this second international conference for youth leaders. It was my privilege to be intimately involved with the Regional Conference in/for Africa. I believe (implicitly) that this enriching contact between churches with a Reformed confession should be encouraged and is in the interest of congregational youth work. It is in fact a matter of integrating youth into the full life and work of the RES.

\section{IMPORTANT PRINCIPLES OR DEPARTURE POINTS}

In principal youth is an essential part of the church. To integrate the young into the full life and work of the church is not to make them something which they are not yet. It is simply to help the adult members to accept the young for what they already are and to help the young realize who they are and what may be expected of them. Any local church that draws upon the true meaning of the covenant, baptism and confession of faith should be filled with the above mentioned view of youth. The Bible makes it impossible to view it differently. Youth are no supplement to the church, no peripheral connected group of people. They are part and parcel of the local church. The complete congregation comprises of parents and children (compare for example Deut 6; Matt $18: 1-6$; $19: 13-15$; Eph $6: 1$ - 4; etc). Kenneth D. Gangel correctly says: "The Christian young person needs to realize that because he is a part of the church, the body of Christ, he has obligations and responsibilities to his local church" (Irving \& Zuck, 1977, p. 37). Corbett and Johnson once wrote: "Youth ministry is more than 'preparing youth to become a part of the church'. It is youth, who are a part of the church now, becoming involved in mission in their world" (Corbett \& Johnson, 1972 p. 162). Or as S. Little put it: "they are part of the ministering body of Christ within which they are supported and equipped for the fulfilling of their common calling" (Little, 1968 p. 11).

This emphasis is a comparatively recent development. "For generations, perhaps throughout Christian history, the church has been organized for adults. If children have been considered at all, it is as the appendages of their parents, accepted into the church because they belonged to a Christian household, but not really recognized until they were able to enter into adult membership. So, for example, the liturgies of the church have been organized as adult activities, and to a large extent children have been ignored" (Barrett, 1982, p. 28).

Integrating youth into the full life and work of the church in many ways asks for a rather radical and total conversion in the minds of adults to the fact that youth are an essential part of the local church. This truth should be in the focus of the church board, the adult leaders, teachers, parents and not the least in 
the focus of the pastor. It must fill their hearts and minds and do so with enthusiasm and gladness. If this is not true every attempt to give them a greater share in worship services will prove to be ad-hoc, short term entertainment. To the young it may prove to be cosmetic and phony.

2.2 A second principle of the utmost importance to our subject is the prominent role of parents in the lives of children and thus in the youth ministry of the church. In modern day society (and church?) individualism has taken over the minds of people. Children are often regarded as free individuals. The duty of parents is to stay out of their way in order to let them develop as individuals with lots of inner resources waiting to develop and be developed. Though the Bible teaches us respect for the individual, God gives all our youth ministry principles in terms of the household, the oikos, the family. (Cf. Gen 12, 17; Deut 6; Jos 24 : 15; 1 Sam 1 - 3; Eph 6; Col 4; Ps 127, 128.)

The basic principle for Reformed youth ministry is the covenant and the covenant is spelt out in family terminology. Though G. W. Peters is a Baptist, he correctly asks: "Who has blinded us against the divine order that we should so completely neglect it . . . Could we have shifted and drifted from the divine ideal and apostolic norm without realizing it? Have our additions, which are good and legitimate, overshadowed the main stream (the family - MN) of God's flow of blessing?" (Peters, 1972 p. 167).

The question can be asked with right whether our youth ministry is building the family or whether it is taking it apart. Did the church take over the 'way of thinking' so well known to independent interchurch youth movements? They most often view a child or youngster as an independent scholar, student or working boy or girl and minister to them completely loose from the home and parents. In this way children are often evangelized out of their homes, thus bypassing the parents and in so many cases causing a tragic break in the most important relationship within which God created that young life.

'To what extent is the church doing the same? Integrating youth into the life and work of the church in worship means a comeback to the basics. God gives parents to children to worship (while they are young, $\pm 0-5$ ) on their behalf, to listen on their behalf, to obey on their behalf - and most of all to translate the worship, service and message of the church to them. A great responsibility rests on parents to act as 'differentiators' in the worship service. It is impossible for a pastor to take every worshipper (in his or her different age group) into account. God gives parents a natural kind of ability to differentiate in the most natural way. This is something wonderful and the Church must be aware of it and utilize it to its full extent. If a Reformed church doesn't do it, who will - and if we neglect it - "who has blinded us against the divine order . . "Ter Welle said at Lausanne: "Parents are the first representatives of God to their children" (Douglas, 1975, p. 726).

2.3 There is a third 'departure point' that I would like to stress. It is the importance of the catechetist in the total youth ministry of the church 
and especially in worship. 'l'hey are busy with what is considered to be the most important part of the youth ministry in the Reformed tradition. "On behalf of and entrusted by the congregation they teach and train covenant members to confess their faith in God the Father, the Son and the Holy Spirit and to join the body of professing members. In doing this they have the duty to build upon what is done at home by parents. Catechesis is to a great extent 'futile' if it isn't backed up by the home. Research figures show positively that the home still is one or even the most important influence upon youth. What happens or does not happen in the home has its influence on children in a most deciding way. Kohnstamm put it thus (freely translated - MN) : "It is not over emphasized to say that the molding of a view of life (in the broad sense) for $90 \%$ is caused by the influence of father and mother - not only by imitation, but in contrast too" (Kohnstamm, 1948, p. 277). The teacher should take this into account and he/she has the duty to play an important part in the ministry to parents in order to lay the right foundation and to provide the correct attitude towards the church and its worship services.

In this regard there is another important principle in the integration of youth into the full life and work of the church in worship. It is the important role that the attitude, the life and work of the adult members play in youth work. It is true that success of each part of youth ministry stands in direct relation to the quality and the 'attractiveness' of the life of the adult part of the local church. Te Winkel to my mind correctly says that the congregation and its way of living and doing is the identification-point for the young. They should be a living example of people moving towards the future though at times it may be groping and uncertain. "In worship and in study, in koinonia and in action, in love for each other and for the world, pastoral and in diakonia", they should be an example of the body of Christ under His Lordship (Te Winkel, s.a. p. 114).

Te Winkel continues and says that if this is to happen, a relationship is to be created amongst the "heart of the Gospel, the heart of the local church and the heart of the youth". And it is exactly here that the enormous responsibility of the catechetist lies. It is their duty to listen to the heart of the Church (i.e. supposed to be the heart beat of the Gospel) and to listen to the heart of the children. In the person and through the person of the catechetist these two (three) should meet each other (p. 115).

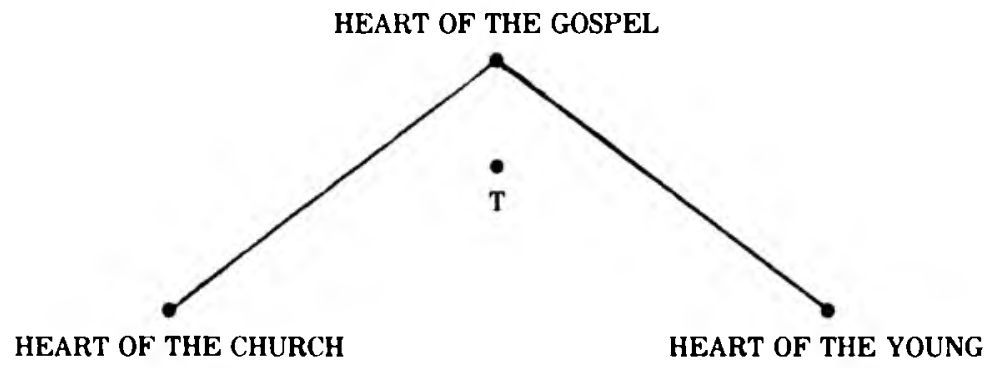

By building on the foundation laid by the parents and by using the example of the 'adult-congregation', inspired by the contents and the 


\section{In die Skriflig}

power of the living Christ, the catechetist can prove to be the best teacher in worship and towards worship. Thus the catechism classes and the co-ordinated youth movement can become a gymnasium in training to worship.

\section{WORSHIP}

Before we draw some practical conclusions about integrating youth in worship, it is necessary to say something about worship.

\subsection{What is 'worship'}

It is rather difficult to express this. It is at least a deed where we in full surrender of our whole being, reach out to God in prayer, thanksgiving, adoration and acknowledge Him in the richness of His Godlike glory. It is the deepest way to answer to God's creative and saving deeds of love (Ps 100;107; 111; 116;146; 150; Rom 11;33-36;1 Cor 8:6; Fil 2: 6 - 11; Col $1: 15-20)$. Though the whole life of a Christian should be one of adoration and glory to God, it is true that the worship service is supposed to be the place where worship is to be found in its purest and most beautiful form. In the worship service God's people are in His temple, at His mountain (Ps $43: 3$ ). They are there to bow in humble adoration before their King - to worship Him with all they are and have (Barnard, 1981, p. 443-4).

\subsection{What then is a worship service?}

3.2.1 My task is not to speak on the worship service as such. That's a topic on its own. Within the Reformed theology it is more or less generally accepted that the simplest way to say what a worship service is, is: It is an encounter between the Triune God and His gathered people. This encounter happens in the form of a dialogue between God and His people and amongst the believers themselves. In this dialogue the total new life in Christ is on the table (Barnard, 1981, p. 489). God Himself, and His salvation, are the all important focus point and centre of the worship service. In the worship service the body of Christ expresses its faith as a gift of God in order to praise and worship God Himself (Goltermann 1951, p. 8). Jonker adds another dimension when he describes the liturgy as the way in which the dynamic Word of God happens and the way in which the congregation gets the opportunity to react to this dynamic Word of God (Jonker, s.a., p. 45).

3.2.2 In the worship service a lot of important things are at stake: The worshipping of the almighty God; the experiencing of the promises valid for those who are in His presence as well as an honest reaction towards the truth of God Himself and His Word. What happens then in this service is of great importance to the whole congregation. How it happens is also very important.

To a great extent the worship service is a concentrate or a summary of the Gospel. The body of Christ is not just on-lookers looking at a short drama of the acts of salvation, but they are in a real and intimate way part of this dialogical encounter with the God of their salvation. In the worship service God Himself is in action and the congregation itself takes part in the celebration of the salvation. 
3.3 The importance of the worship-character of the service can not be over-emphasized. Baxter once wrote: "True reverence is vital to our sanctuary services if there is to be persuasive soul winning, rich spiritual life in our church members, and a moving of God's Spirit among us" (Baxter, 1974, p. 156-157).

A worship service with this quality grows from the heart of a praying liturgist who himself worshipped before he leads God's people in worship. He and everyone involved in the ministry within the local church therefore must try to create a spirit of prayer and expectation in and about the worship service. This is possible if and when Christians pray for the service in private; and children join in prayer for the worship services at home; when all the different prayer meetings of women, youth and church committees focus more explicitly on prayer for the worship services. We need an organized effort to increase the importance of worship amongst the people of God and to get them involved and full of expectation even before it's time for the service itself. God's people live for 'Sunday' and they live because of 'Sunday'.

3.4 At the same time the local church should be trained in worship. Ireson correctly says that worship must be preceded by instruction and instruction must be followed by training in worship" (Ireson, p. 22). "We have taught children in our Sunday schools about prayer and about the church, in the hope that they would afterwards put these desirable things into practice. There is no need for surprise or disappointment that they do not, and in many cases cannot. Our first task is to enable them to experience prayer and worship, and to experience the fellowship of God's family, the Church, as living realities" (Ireson, p. 37 cf. also p. 58-85). The problem is even greater. Adults may well learn to worship through instruction, but children learn through experience. Therefore adults will have to be taught by instruction to worship in reverence in such a way. that youth who learn through experience and intense observation may 'know' they are part of it and in a special way partaking in worship themselves.

In such a worship service they experience something of the 'jenseits' and the to them still undefined longing for peace in Him, the worshipable Lord. Little correctly says that the 'response' of worship, then, is not just a matter of 'being informed' intellectually. It is a matter of involving the whole person in celebration of God's creative and redemptive acts in man's behalf . . . It is only as they find in it relevance to our world, a response to God's continuing acts, that young people will be able to enter meaningfully into the worship of their congregations" (Little, 1968, p. 152). The questions are:

$\star$ whether we are doing enough to train adults as well as children in worship

whether the parents and other adults are worshipping in such a vivid way that children themselves learn by observation and experience to worship.

3.5 The above mentioned does not imply a worship service where the atmosphere is so 'heavy' that people react out of forced fear, rather than 


\section{In die Skriflig}

devout worship. It should be a warm, friendly atmosphere; an atmosphere full of reverence that at once makes the worshipper feel to flee and to hold on in adoration - like Peter in Luk $5: 8$. It is the true and Biblical "fear of the Lord" that we need so desperately.

Reverence and worship must be the atmosphere within which the service breathes. It is obtained only through prayer and trust in the Lord who is to be worshipped, but is carried by the liturgy and the Spirit controlled handling of the liturgy.

3.6 The liturgy carries, escorts and regulates this loaded encounter with God. To cater for the young the liturgy should be handled with youth in mind. This requires simplicity and intelligibility. The official church and the liturgist himself have a responsibility towards God's people to help them worship in terms that they understand and that is meaningful to them. Hoffman correctly calls simplicity and intelligibility in the worship service a demand of love for the neighbour (Hoffman, 1966, pp. $11,12)$.

This also means that the liturgy must interpret and escort the timeless into the time, into the here and now - understandable to the congregation who worships now at a specific place and time in history. It is at this point that the old and the young often don't agree. Older people often cling to the well known as if it is the gospel itself while youth often rejects the well known as old and behind the times. Most probably the liturgy known to the young was invented by people other than themselves or even their parents' generation.

To my mind it is not always necessary to invent new liturgies (though it is always the responsibility of the Church to be busy with research and the introduction of new possibilities within the reformed tradition) but the liturgy of a church must make provision for healthy variation within one or more prescribed forms. There should be enough suppleness and the different elements should be raised in a sensible, inspiring way for the sake of participation, simplicity and intelligibility. Without changing the elements in such a way that it appears to be strange and new every time, the leader should take care against a liturgy that makes worship 'automatic' because it is too well known and exactly the same each time. Barnard put it thus: (freely translated MN) : "As set form and freedom, the traditional and the new, order and the spontaneous, the liturgical and the ex tempore, the formal and the charismatic, the sacramental and prophetic are closely combined. They are in a certain tension with each other but only in the maintenance of this bipolaric tension is it possible to maintain a healthy and blessed implementation of both in the worship service . . . Thus the "peace and the movement are maintained; thus the congregation keeps to the well known that gives them a feeling of safety (and you may add the frankness to take part - MN) as well as the variation that gives the necessary impetus for new understanding and experience" (Barnard, 1981, pp. 500, 502).

The above mentioned applies also to the music and singing in worship services. Too often the church canonises songs and music from previous times. The church at times gives the impression that nothing has happened in the field of music for the last hundred or more years. In the meantime youth is well aware of the musical revolution since the 
1950 's! Youth should be beware that serving the Lord in music and song requires nothing less than the best in melody and words - but to pretend that nothing that has been produced this century is good enough, is hard to believe. At the same time no one can over estimate the importance of singing, good singing and music in worship. Van der Made wrote: "When you are in rapture you start singing (als cen mens in vervoering geraakt, gaat hij zingen) ... and thus singing is an essential part of life of a Christian and it has a legitimate place in the liturgy" (Van der Made, 1963, p. 221).

\section{DIFFERENT OPTIONS OPEN TO THE CHURCH}

Let me once more summarize the principles that help us to judge the different options.

$\star$ Within a reformed church, worship services must be aimed at the whole family. The congregation is to a great extent nothing else than a gathering of covenant families.

* Differentiation normally is implied by the parents themselves and the liturgist - though it is possible to differentiate by way of exception amongst the different age groups within or next to the normal worship.

$\star$ All the principles for a worship service in the Reformed Theology should be taken into account.

* Above all the all important centre of the worship service is not man - adult or youth - but God Himself

$\star$ Because God is in the centre, man - adult and youth - has his important place in this encounter. It is not a matter of putting man in the centre but of taking man into account as God did and still does. To ignore the importance of man may prove unfaithfull to God in the same way as it is unfaithfull to overestimate man.

* For a more detailed discussion on differentiation in more than one way it may help to read: J. W. Beerekamp: De Jeugddienst, 1952.

\subsection{Family worship for special occasions}

A lot of literature is available to the German reader on 'Familiengottesdienste'. (See biography at the end of this paper.) It is not altogether clear what exactly is meant by a 'Familiengottesdienst', but at least it is a special occasion where the children and young people are invited to share in some kind of special happening with their parents as a family. This may be to stimulate dialogue between parents and children (Gesprachseroffnung) to practice certain Christian rolls in this life (Rolleneinubung), to share in a 'Fest' or to demonstrate koinonia (Georg Kugler \& H. Lindner. 1973, p. $29-31$ ).

The problem with the 'Familiengottesdienst' to my mind is the fact that it is something special and the danger is that it may become some kind of performance which the congregation is encouraged to expect to be entertained. And this we dare not call 'worship'. To worship as families and as the household of the Lord is never an extra to the normal Sunday worship service. It is compulsory to a Church of Reformation to get together and to be together as families in worship. Putting up some or other programme, how good it might be, to treat families is in more than one way an emergency measure. As far as I can sense this is exactly 


\section{In die Skriflig}

the case in the 'Volkskirche' where you nurture a 'Kerngemeinde' and on some special occasions try to get the children and their parents together. This may prove as Kugler is well aware to be a short term solution as the 'Jugendgottesdienste' to some extent has proved to be (Kugler, 1973, p. 41).

4.2 Worship which, on a particular occasion, departs from the normal liturgical pattern, and takes a simplified form with children particularly in mind

This may even be the general form of the service described in 4.1 above. I would like to join John Barrett in his evaluation of this type of worship service.

"First, if worship is to be family worship, then children must be held in mind when planning it. To ignore them would be to deny their place within the family of the church, and it is right to think of ways in which children of all ages can be involved in the service and the presence celebrated. But to concentrate only on the children to the exclusion, or near exclusion, of the rest of the congregation would also be to make a mockery of family worship. A service for children is just that - a children's service; it is not family worship!

Further, while it is important for the children to realize that they are valued enough within the church family to be given special attention, it is important also for them to realize that others within the church family are equally valued. Only then will they get a sense of belonging to a family.

Thirdly, while it is vital for children to be able to enter into the worship at their level, and, as we have suggested in an earlier chapter, they will want to and find it natural to do so, if children are encouraged to think that worship is an activity which is primarily for children, they will stop attending services as they begin to grow to adulthood, at the same time as they leave behind other activities which they now regard as childish. There is some evidence that this is exactly what happens with children of eleven or twelve, who find themselves bored, patronized or, worse still, embarrassed in services pitched mainly on the level of children of the primary age-group.

One last point. There is something radically wrong with the normal liturgical pattern if it is necessary for it to be modified seriously to involve children. Either that, or there is something wrong with the church's understanding of the nature of worship, and of the child's place within it" (Barrett 1982, p. 63-64).

\subsection{Worship in which the church community is together for part of the time}

Barrett is correct when he states that "this is probably the normal practice for those churches which claim to have family worship every Sunday" (Barrett, 1982. p. 65). A few remarks should be made on this option.

$\star 1$. To my mind this is acceptable from time to time especially when an educational purpose is the aim. It then should not be a worship service, but an educational service. To do this in order to improve worship is not justifiable. 
$\star 2$. In connection with the preceding it must further be remembered that this way of accommodating youth interrupts an act of worship which is presumably meant to be a whole. Young people later may associate worship with prayer, confession of faith, the reading of the Law and a hymn or two.

The reason given for taking the children apart is the intelligibility of the sermon. This of course is a serious reason, but it is educational in nature and has to be treated in a different way. The question may well be asked whether it is educationally speaking right to interrupt an act of worship and take the little ones apart from their own families and for that matter from the gathered family of God.

$\star 3$. The unique oneness of the body of Christ gathered in worship must remain the guiding principle for the normal worship services of the church. This does not mean that the oneness is harmed when different age groups at times meet seperately. It may even confirm the oneness and create a longing to be together next time - however, the normal pattern for a healthy congregation is to be together as parents and children, old and young, rich and poor, etc. before our Lord.

4.4 Every Sunday worship services in which families and the whole church family is expected and encouraged to share and in which a conscious effort is made to involve everyone, from the oldest to the youngest (Barrett, 1982, p. 67).

4.4.1 This may truly be called family worship. This to my mind is the only Biblical (i.e. Reformed) way to integrate youth into the full life and work of the church in worship. Of course it is the more difficult way, but if you want to stay true to principles given to us in Scripture, you do not have much of a choice. In this respect the gathering of God's people is different to the differentiated world in which we live. It seems as if specialization urges us to differentiate more and more and in doing so we take apart fathers and mothers, parents and children, brothers and sisters, brothers and brothers, and sisters and sisters. The church should be the one place, even though some time in future it may happen to be the only place, where people who God has knitted together so closely will be together. The covenantal binding, the koinonia constituted by our common faith in Jesus Christ our Lord, our common profession of faith makes it more than possible - it makes it compulsory.

4.4.2 The great question is How? Adding (and in some way summarizing):

$\star 1$. Teach parents and through them (or for the older children and young adults directly) youth the importance of being the Church of God and the body of Christ in worship. We must rid ourselves of the underestimation of the worship service and promote to the most important meeting of the week. This of course will demand hard work in prayer, in preaching, in and throughout the total teaching ministry of the Church. $\star 2$. Train adults and children in worship. Though you never 'play' worship it may be good to 'practise' worship during the service and in the meetings of the youth movement. As long as the focus is the worship service of the total family of God there is nothing wrong with a worship service 'in de kleine' during a youth meeting.

$\star 3$. Plan (and pray) for worship and plan the worship service. To my mind it is impossible to do it without a group of people from different 


\section{In die Skriflig}

age-groups in the congregation. The church board can appoint such a group every semester. It is their duty to represent the age groups, the different target and interestgroups in the congregation. The pastor discusses the sermon with them. They may even take part in the 'invention' and the formulation of the theme. The 'expert' supplies the true meaning of the text and the 'experts' in life supply the 'put-in' as far as relevance to the now and here of people in different age groups is concerned.

In the same way they plan the liturgy together with the pastor: The text for the votum, the hymn to start with; they supply the material for the intercession, etc. To my mind there is nothing wrong in letting youngsters by way of exception lead in prayer, read from the Bible or give up the closing hymn. It is in any case the congregation that is worshipping.

Even when the 'liturgist' leads he must be deeply aware of this fact and stand guard against the evil of doing it on benalf of the people of God. Nothing is more deadly to the nature of congregational worship.

The above mentioned method is a long one, but it is fruitful and satisfactory. Besides, time invested in planning the worship service is most probably a pastor's best investment.

$\star 4$. In this way a spirit of expectation will emerge in and around the worship service. This brings me to what I consider of central importance at this point: The pastor himself. He must trust God to be cleansed and surrendered so as to lead this encounter with reverence filled with love, warmth, compassion and joy. This is closely connected to what has already been said - youth normally takes part and feels part of a congregation where the adult members worship in a vivid and joyful way - especially when it is obvious that they love the Lord, love each other and enjoy it. The share of the 'liturgist' in this is undeniably important. To the young he is the 'example' of what it means to be a 'fulltime worshipper'. Needless to say he must be his true self, speak as he normally does, with reverence keep his sense of humor and put himself completely into what he is doing. Of course this requires concentration after serious preparation and meditation.

$\star 5$. Though I consider it an acceptable possibility to organize a crèche for small children (up to three years) it may not even be necessary. When the above mentioned happens and Daddy and Mommy take part with all their hearts, the children are easily interested and fully involved. Barrett correctly notes that if children are bored and restless, it may be that there is something wrong with the worship, not with the children" (Barrett, 1982, p. 69).

$\star 6$. Differentiate in three possible ways

- Utilize to its maximum the possibilities of parents. Ask them from time to time to 'translate' to their little ones what has just happened or what is being said. This could be a common procedure in every church.

- Take children into account when announcing different moments in the liturgy. Of course we must also take the adults, the young adults and the aged into account. This is why the preparation and planning is so all important. 
- Plan for educational types of services where each age group gets its share. To my mind the evening service can much more 'cater' for this kind of service. The congregation may divide into three or more different groups (if the space is available) and join again later for prayer, singing and benediction.

$\star 7$. From time to time it may be valuable and necessary to plan a 'special' family worship service. Here all the material used for the 'special occasion' Familiengottesdienst is of great value and we can learn a lot. The difference is that family worship is the normal pattern and from time to time it may prove to be of great value to let youth do something special - singing, dramatize a part from Scripture or ask their parents questions, etc. In the 'Familiengottesdienst' a lot of possibilities lie open. One of them that is worth considering is what is called 'problemorientiester Familiengottesdienst' (Kugler, 1973, p. 31).

8. Help older people to develop an evangelical openness. The law tends to close down the minds of men and women. The example of the Scribes and pharisees is enough proof of this. Smart succeeded brilliantly in showing what disastrous consequences follow when education in dogma and worship is separated. It leads to legalism and moralism (Smart, p. 13 - 17). He correctly speaks about the "suffocating fog of moralism" (p. 77). When we suffocate in this fog we are producing "ordinary Christians . . . the non-evangelizing, incoherent type of Christian, who is already the stand type in most churches" ( $p .101$ ).

It seems as if youth has an extra organ to sense openness, integrity and love. It is more important to help create an adult membership with an evangelical openness to the experimental-attitude of the young than to make a lot of short-term often cosmetic changes. The young need a congregational muratorium where they are allowed to 'experiment' in worship under the guidance of their parents and other leaders. Therefore youth at their part too must learn to be open to accept that which is not acceptable to the Church (das Unverfügbare) and older people should try to be open to the unknown which is not unacceptable just because it is new.

\section{IN SHORT}

Integrating youth into the full life and work of the church in worship requires:

* Integrating youth in the minds and hearts of the adults in the church

* Taking the importance of parents and family into full account

$\star$ Planning for normal Sunday to Sunday family worship services where the old and the young are equally important

* A fresh encounter, each week, for the leader in worship with the living God

$\star$ A Spiritfilled 'liturgist' leading the vivid, dialogical encounter between God and His people

$\star$ An adult community who acts as an identification point for children and young people

* A new appreciation of worship, worship services and the church as a worshipping body of Christ

- A fresh view on our covenantal God - you may call it an eschatological view on the One on the Throne and before Him thousands of 


\section{In die Skriflig}

thousands gathered in worship proclaiming: "Victory to our God who sits on the throne, and to the Lamb! Amen! Praise and glory and wisdom, thanksgiving and honour, power and might, be to our God for ever and ever! Amen" (Rev. $7: 10,12$ ).

May we and our children be there to join and to participate in that worship service! And may we already succeed in teaching them here to participate in worship!

\section{LITERATURE}

1. Barnard, A.C., Die Erediens. Pretoria: NG Kerkboekhandel, 1981.

2. Beerekamp, J.W., De Jeugddienst. Nijkerk: Callenbach, 1952.

3. Baxter, J.S., Rethinking of priorities. Grand Rapids, Mich.: Zondervan, 1974

4. Barrett, J.C.A., Family worship. London: Epworth, 1982.

5. Daiber, Karl-Fritz, e.a., Gemeinden erleben ihre Gottesdienste. Gutersloher-Mohn: Gutersloh, 1978.

6. Dekker, G., Jonker H. e.a., Wat vindt $u$ van de Kerkdienst? Wageningen: Zomer \& Keuning, 1971.

7. Douglas, J.D., Let the earth hear His voice. Minneapolis, Minn: World Wide, 1975.

8. Eberts, G., Jugendgottesdienste, Band 3. Munchen; Rex, 1978.

9. Firet, J., Het agogisch moment in het pastoraal optreden (3rd print). Kampen: Kok, 1977.

10. Fischer, H., Thematischer Dialog-gottesdienst. Hamburg: Furche, 1975.

11. Green, H.L., Why churches die. Minneapolis, Minn: Bethany, 1972.

12. Heitink, G. en H. Hogenhuis, Kerk en jongeren. Kampen: Kok, s.a.

13. Hoffmann, K., Gottesdienst fur junge Leute. Stuttgart: Ehrenfried Klotz, 1966.

14. Irving, R.G. \& R.B. Zuck, Youth and the Church (8th print). Chicago: Moody, 1972.

15. Kohnstamm, P., Jeugd tussen God en chaos. 's-Gravenhage: Nijhoff, 1948.

16. Kugler, G. en H. Lindner, Neue Familiengottesdienste 2. Gutersloher-Mohn: Gütersloh 1973.

17. Kugler, G. en H. Lindner, Neue Familiengottesdienste 2. Gutersloher-Mohn: Gutersloh 1976.

18. Kugler, G. en H. Lindner, Neue Familiengottesdienste 4. Gutersloher-Mohn: Gütersloh 1980 .

19. Little, S., Youth, world and church. Richmond, Virginia: John Knox, 1968.

20. Martin, J. en B.J. Bailey, Worship with youth. Philadelphia: Christian Education, 1962.

21. Minuchin, S., Families and family therapy. London: Tavistock, 1974.

22. Nel, M., Jeug en Evangelie, Pretoria: NG Kerkboekhandel, 1982.

23. Mitschke, H., Konfirmation (Gottesdienst mit Konfirmanden). Gutersloher-Mohn: Gütersloh, 1987.

24. Schmidt, H.G., Zum Gottesdienst morgen. Munchen: Pfeiffer

25. Smart, J.D., The teaching ministry of the church. Philadelphia: Westminster, s.a.

26. Smith, L., Family ministry. Nashville, Tenn: Discipleship Resources, 1975.

27. Schultz, H.M., Wenn Gottesdienst Freude macht. Mainz: Matthias-Grunewald, 1977.

28. Strommen, M.P., Bridging the gap. Minneapolis, Minn: Augsburg, 1973.

29. Trautwein, D. Kerkdienst als leerproces. Kampen: Kok, 1974. (Original title: Lernprozess Gottesdienst: München: Pfeiffer, 1972. Translated into Dutch by dr. E. de Vries).

30. Te Winkel, J.D., Metterdaad en in der waarheid. Kampen: Kok, s.a.

31. Zuck, R.B. en W.S. Benson, Youth education in the Church (2nd print). Chigago Moody, 1979.

For further reading (also recommended by J. C. A. Barrett):

1. Bolting, M. \& J. Tigwell, Reaching the families. Falcon Books, 1976

2. Davies, J.G., New perspectives on worship today. SCM Press, 1978.

3. Jasper, R.C. (ed)., Worship and the child. Joint liturgical group, 1975.

4. Nevelle, G.J. en J.H. Westerhoff, Learning through liturgy. Seabury Press, 1978.

5. Sutcliffe, J.M. Learning community. Denholm House Press, 1974.

6. Sutcliffe, J.M. Learning and teaching together. Chester House Publications, 1980. 